\title{
Biomarker Response and Biomass Toxicity of Earthworms Aporrectodea caliginosa Exposed to IGRs Pesticides

\author{
Hoda M Nasr ${ }^{1 *}$ and Mohamed El Badawy²
}

${ }^{1}$ Department of Plant Protection, Faculty of Agriculture, Damanhour University, Damanhour, Egypt

${ }^{2}$ Department of Pesticide Chemistry and Technology, Faculty of Agriculture, Alexandria University, El-Shatby, Alexandria, Egypt

\begin{abstract}
Earthworms play key roles in soils and sub lethal effects of environmental toxicants on these organisms should be taken seriously, since they might have detrimental effects on higher ecological levels. In laboratory experiments, we have assessed to investigate the toxicity of two insect growth regulators (IGRs) flufenoxuron and pyriproxyfen at different application rates and exposure times against mature stage earthworms Aporrectodea caliginosa. The effects of these pesticides on the growth rate in relation to the activities of acetylcholinesterase (AChE), polyphenol oxidase (PPO) and glutathione S-transferase (GST) as biomarker indicators were evaluated to elucidate the mechanisms of action. Toxicity studies indicated that pyriproxyfen was more harmful to mature earthworms than flufenoxuron with $\mathrm{LC}_{50}=42.63$ and $60.66 \mathrm{mg} / \mathrm{kg}$ after four weeks, respectively. The reduction in growth rate of all pesticide-treated worms was dosedependent over the 28-day exposure period which was accompanied by a decrease in AChE, PPO and GST activities. Relationships between growth rate and enzyme activities provided strong evidence for the involvement of pesticidal contamination in the biochemical changes of earthworms, which can be used as a bioindicator of soil contamination by pesticides.
\end{abstract}

Keywords: Earthworms; Insect growth regulators; Acetylcholinesterase; Polyphenol oxidase; Glutathione-S-transferase

\section{Introduction}

Agricultural pesticide applications represent a serious hazard to wildlife and ecosystem resources which has led to a growing concern worldwide over the indiscriminate use of such chemicals [1-3]. Pesticides even when present in small quantities, their variety, toxicity and persistence have an adverse effect on non-target organisms. There is an increasing demand for new experimental models that can be used as bioindicators for assessing the health status of terrestrial ecosystem. One of the important organism groups in the environment on which this pesticide can therefore exert unwanted negative effects is the nontarget soil fauna [4].

Earthworms are common soil organisms in most environments, and play an important role in improving structure and fertility of soil ecosystems [5]. They were chosen as an example for non-target soil organisms due to their beneficial role in soil and their abundance was found to be very low in the adjacent areas [6]. They modify soil organic matter both chemically and physically, mix leaf litter with the soil, facilitate the formation and stabilization of soil aggregates and improve soil porosity. The use of earthworms for toxicity testing is highly recommended by the European Communities and is considered as preferred bio-indicators for assessing the environmental health status of chemical pollution [7]. It has been indicated that earthworms may represent up to $60-80 \%$ of the total animal biomass in soil $[8,9]$. Unlike many other soil organisms that are protected by thick cuticle on the exterior of their bodies, earthworms are particularly susceptible to soil chemicals $[10,11]$. Therefore, earthworms are suitable bioindicators of soil contamination and can be used to provide safety thresholds for insecticide applications $[12,13]$. Insect growth regulators (IGRs) as third-generation insecticides have a specific mode of action on insects and a lower toxicity against vertebrates than the conventional insecticides [14]. However, heavy applications of such pesticides in agricultural areas may also impact on non-target organisms in and adjacent to the target areas. Pyriproxyfen is IGR which highly molt inhibitor for a wide range of insects. It is a juvenile hormone analog that suppresses embryogenesis, metamorphosis and adult formation by interfering with the hormonal balance of insects [15]. This compound inhibits chitin synthesis, interrupting the normal physiological process of molting such as suppressing oviposition of adults and reducing the viability of eggs [16]. Treated susceptible pests may remain alive on the plant for three to seven days, but feeding damage during this time is typically very low. Flufenoxuron is one of insect growth regulator pesticides, highly used to control pests by inhibiting of chitin synthesis; this family of pesticides has toxicity to non-target organisms [17]. Families of enzymes, such as oxidoreductases (e.g., superoxide dismutase and catalase), transferases (glutathione S-transferases) and hydrolases (e.g., acetylcholine esterase) in earthworms are regarded as fast and prognostic indices of individual reaction to the environmental stress (Scaps et al.; Saint-Denis et al.; Booth et al.). The aim of this study was to determine the toxic effects of two IGRs, flufenoxuron and pyriproxyfen on the earthworm Aporrectodea caliginosa. The toxic effects of these pesticides on three biomarker responses (acetylcholinesterase (AChE), polyphenol oxidase (PPO) and glutathione S-transferase (GST) were also examined to evaluate the risk to soil organisms and ecosystems.

\section{Materials and Methods}

\section{The insecticides and chemicals}

Formulated flufenoxuron (Cascade, 10\% EC) 1-[4-(2-chloroa,a,a-trifluoro-p-tolyloxy)-2-fluorophenyl]-3-(2,6-difluorobenzoyl) urea and pyriproxyfen (Admiral, 10\% EC) 4-phenoxyphenyl (RS)-2-

*Corresponding author: Hoda M. Nasr, Department of Plant Protection, Faculty of Agriculture, Damanhour University, 22516, Damanhour, Egypt, Tel: 01222237641; Fax: 033923345; E-mail: cohm_hm@yahoo.com

Received September 02, 2015; Accepted October 31, 2015; Published November 03, 2015

Citation: Nasr HM, Badawy ME (2015) Biomarker Response and Biomass Toxicity of Earthworms Aporrectodea caliginosa Exposed to IGRs Pesticides. J Environ Anal Toxicol 5: 332. doi:10.4172/2161-0525.1000332

Copyright: $\odot 2015 \mathrm{Nasr} \mathrm{HM}$, et al. This is an open-access article distributed under the terms of the Creative Commons Attribution License, which permits unrestricted use, distribution, and reproduction in any medium, provided the original author and source are credited. 
(2-pyridyloxy)propyl ether was obtained from Sumitomo Chemicals (Osaka, Japan). Bovine serum albumin (BSA), Folin-Ciocalteu phenol reagent, acetylthiocholine iodide (ATCh I ), 5,5-bis-dithio-bis(2nitrobenzoic) acid (DTNB), glutathione, and 1-chloro-2,4-dinitro benzene (CDNB) were purchased from Sigma-Aldrich Chemical Co., USA. All chemicals were used without further purification.

\section{Earthworms and assay conditions}

Earthworms (Aporrectodea caliginosa) which commonly found in Egypt were collected from dunghills around Bahara Governorate. The worms were carefully brought to the laboratory within an hour along with the moist soil and acclimatized for 7 days under the laboratory conditions in-feeding. They reared in a r tificial soil at $23 \pm 2^{\circ} \mathrm{C}$ in large plastic containers $(38 \times 60 \times 10 \mathrm{~cm})$ covered with muslin cloth according to Heimbach [18]. Earthworms used in this study were adults with well-developed clitella. As earthworms are hermaphrodite, no sexual differences were taken into account. The adults were removed from the artificial soil $24 \mathrm{~h}$ before $\mathrm{u}$ se and stored in Petri dishes on damp filter paper in the dark at $23 \pm 2^{\circ} \mathrm{C}$ to void gut contents. The artificial soil was prepared using $70 \%$ industrial sand, $20 \%$ kaolin clay and $10 \%$ sphagnum peat moss and the $\mathrm{pH}$ were adjusted to $6.0 \pm 0.5$ by the addition of $\mathrm{CaCO}_{3}$.

\section{Growth inhibition of earthworms}

Before weighing, the worms were sorted, washed with tap water, and blotted with filter paper, and then weighed. The weights of each earthworm were determined after 1,2,3, and 4 weeks of exposure and compared with controls. Such weight determination was performed using four replicates. The weight of earthworms in each dose group reported from the various exposure periods was then used to compute the growth inhibition as follows:

$$
\text { Growth inhibtion }(\%)=\left(\frac{\mathrm{C}_{\mathrm{L}}-\mathrm{T}_{\mathrm{L}}}{\mathrm{C}_{\mathrm{L}}}\right) \times 100
$$

Where $\mathrm{C}_{\mathrm{L}}$ is the mean larval weight $(\mathrm{g})$ in the control and $\mathrm{T}_{\mathrm{L}}$ is the mean larval weight $(\mathrm{g})$ in the treatment.

\section{Acute toxicological tests}

The pesticides were dissolved with distilled water and thoroughly mixed into the artificial soil at concentrations of 10,25, 50,100 and 200 $\mathrm{mg}$ (a.i)/Kg soil for flufenoxuron and 15, 37.5, 75, 150 and $300 \mathrm{mg}$ (a.i)/ $\mathrm{Kg}$ soil for pyriproxyfen. Controls were prepared in a similar way, except that, distill water was only add ed to the artificial soil. The moisture content was adjusted to $35 \%$ of the final weight and monitored twice a week. All exposures were conducted in $23 \pm 2^{\circ} \mathrm{C}$ under continuous light. Four exposure periods were tested: 1, 2, 3 and 4 week and for each duration or dose, four replicates consisting of 10 earthworms pooled together were analyzed. Mortality was counted every week by washing away the artificial soil. Earthworms were regarded as dead when they did not react to a mild mechanical stimulus [19]. LC $_{50}$ values were computed using probit regression modeling for the mortality data [20].

\section{Biochemical studies}

The treated or untreated worms were removed from the artificial soil, stored for $3 \mathrm{~h}$ in Petri dishes on damp filter paper, and placed in the dark at $23 \pm 2^{\circ} \mathrm{C}$ to void gut contents. The definite weight of larvae was homogenized in $3 \mathrm{~mL}$ of potassium phosphate buffer $(\mathrm{pH}$ 7.0) using a glass/Teflon Homogenizer on ice. The homogenates were centrifuged at $6000 \mathrm{rpm}$ for $20 \mathrm{~min}$ at $4^{\circ} \mathrm{C}$. The final supernatant was subjected to protein, AChE, PPO and GST assays. The biochemical constituents were determined, after 4 weeks of exposure. The Lowry et al. [21] method was used to determine protein content. The absorbance of the developed blue color was measured at $600 \mathrm{~nm}$ using a Unico 1200-Spectrophotometer. The sample protein content was determined by comparing to the standard curve of BSA. The activity of AChE was determined by the colorimetric method of Ellman et al. [22], using ATChI $(0.075 \mathrm{M})$ as substrate. The specific activity of AChE was expressed as $\triangle \mathrm{OD}_{412} \mathrm{~min}^{-1}$.mg protein ${ }^{-1}$. PPO activity was determined by following the oxidation of the pyrocatechol substrate at $420 \mathrm{~nm}$ for $5 \mathrm{~min}$ in $0.1 \mathrm{M}$ phosphate buffer $(\mathrm{pH} 6.8)$ at $30^{\circ} \mathrm{C}$ [23]. The specific activity of PPO was expressed as $\mathrm{OD}_{420} \mathrm{~min}^{-1} \cdot \mathrm{mg}$ protein ${ }^{-1}$. GST activity was measured as described by Saint-Denis et al. [24], using CDNB as substrate. The specific activity was expressed as $\mathrm{OD}_{340} \cdot \mathrm{min}^{-1} \cdot \mathrm{mg}$ protein $^{-1}$.

\section{Statistical analysis}

All quantitative estimations of toxicity parameters were based on four replicates and the values were expressed as mean \pm standard error. The probit analysis was conducted using SPSS 12.0 software (Statistical Package for Social Sciences, USA). A regression was made of mortality against concentration and the lethal concentration caused 50\% mortality $\left(\mathrm{LC}_{50}\right)$ was obtained. The $95 \%$ confidence limits for the range of $\mathrm{LC}_{50}$ values were determined by the least-square regression analysis. The data on growth weight and enzyme activity were each subjected to one-way analysis of variance (ANOVA). Results with $p<0.05$ were considered significant with all statistical significance.

\section{Results}

\section{Acute toxicity of flufenoxuron and pyriproxyfen to $A$. caliginosa}

This study was carried out to compare the acute effects of flufenoxuron and pyriproxyfen separately to A. caliginosa. The median lethal concentrations $\left(\mathrm{LC}_{50}\right)$ values with corresponding $95 \%$ confidence limits and slopes of the lines of toxicity of two pesticides after 1, 2, 3 and 4 weeks of exposure period are shown in Tables 1 and 2. The acute toxicity of flufenoxuron to earthworms showed a toxic action increased over time, where the $\mathrm{LC}_{50}$ values decreased from $66.41 \mathrm{mg} / \mathrm{kg}$ after one week to $60.66 \mathrm{mg} / \mathrm{kg}$ after four weeks. While, $\mathrm{LC}_{50}$ values decreased from 56.79 to $42.63 \mathrm{mg} / \mathrm{kg}$ after exposure period 1 and 4 weeks, respectively, in case of pyriproxyfen (Table 2). The to $\mathrm{x}$ icity of pyriproxyfen to earthworms after 28 days was higher than flufenoxuron, with $\mathrm{LC}_{50}$ 42.63 and $60.66 \mathrm{mg} / \mathrm{kg}$, respectively. According to the regulation of environmental risk assessment of agricultural pesticides, the proposed standard of toxicity is $\mathrm{LC}_{50}<1 \mathrm{mg} / \mathrm{kg}$ of highly toxic pesticides, $1-10$ $\mathrm{mg} / \mathrm{kg}$ for medium toxic pesticides, and $>10 \mathrm{mg} / \mathrm{kg}$ for low toxic pesticides [25]. With this rule, the acute toxicity of pyriproxyfen and Flufenoxuron into adult worms was found to be low.

\begin{tabular}{|c|c|c|c|c|}
\hline $\begin{array}{c}\text { Exposure } \\
\text { period }\end{array}$ & $\left.\mathbf{L C}_{\mathbf{5 0}}{ }^{\mathbf{a}} \mathbf{( m g / k g}\right)$ & Slope $^{\mathbf{b}} \mathbf{\pm} \mathbf{S E}$ & $\begin{array}{c}\mathbf{I n t e r c e p t}^{\mathbf{c}} \\
\mathbf{\pm ~ S E}\end{array}$ & ${\mathbf{( \mathbf { X } ^ { 2 }}}^{\mathbf{d}}$ \\
\hline $\mathbf{1 W}$ & 66.41 & $3.77 \pm 0.28$ & $-6.88 \pm 0.52$ & 14.68 \\
\hline $\mathbf{2 W}$ & 63.64 & $3.49 \pm 0.26$ & $-6.30 \pm 0.47$ & 5.091 \\
\hline $\mathbf{3 W}$ & 61.82 & $3.84 \pm 0.29$ & $-6.87 \pm 0.52$ & 10.11 \\
\hline $\mathbf{4 W}$ & 60.66 & $3.71 \pm 0.28$ & $-6.62 \pm 0.50$ & 12.72 \\
\hline
\end{tabular}

aThe concentration causing $50 \%$ mortality of the earthworm. Results of $\mathrm{LC}_{50}$ are expressed as mean of four replicates \pm standard error. ${ }^{b}$ Slope of the concentrationmortality regression line \pm standard error. Intercept of the regression line \pm standard error. ${ }^{\mathrm{d}} \mathrm{Chi}$ square value.

Table 1: Acute toxicity of flufenoxuron on mature earthworms (A. caliginosa) after exposure period 1, 2, 3 and 4 weeks. 
Citation: Nasr HM, Badawy ME (2015) Biomarker Response and Biomass Toxicity of Earthworms Aporrectodea caliginosa Exposed to IGRs Pesticides. J Environ Anal Toxicol 5: 332. doi:10.4172/2161-0525.1000332

Page 3 of 7

\begin{tabular}{|c|c|c|c|c|}
\hline Exposure period & $\mathbf{L C}_{\mathbf{5 0}}{ }^{\mathbf{a}} \mathbf{( \mathbf { m g }} \mathbf{\mathbf { k g }} \mathbf{)}$ & Slope $^{\mathrm{b}} \pm \mathbf{S E}$ & Intercept $^{\mathbf{c}} \pm \mathbf{S E}$ & $\mathbf{( X}^{\mathbf{2}} \mathbf{d}^{\mathbf{d}}$ \\
\hline $\mathbf{1 W}$ & 56.79 & $2.56 \pm 0.19$ & $-4.50 \pm 0.35$ & 12.09 \\
\hline $\mathbf{2 W}$ & 46.93 & $3.20 \pm 0.24$ & $-5.36 \pm 0.43$ & 2.24 \\
\hline $\mathbf{3 W}$ & 45.39 & $3.29 \pm 0.25$ & $-5.45 \pm 0.44$ & 0.89 \\
\hline $\mathbf{4 W}$ & 42.63 & $3.21 \pm 0.24$ & $-5.24 \pm 0.42$ & 0.81 \\
\hline
\end{tabular}

aThe concentration causing $50 \%$ mortality of the earthworm. Results of LC $_{50}$ are expressed as mean of four replicates \pm standard error. ${ }^{b}$ Slope of the concentrationmortality regression line \pm standard error. "Intercept of the regression line \pm standard error. ${ }^{\mathrm{d}} \mathrm{Chi}$ square value.

Table 2: Acute toxicity of pyriproxyfen on mature earthworms ( $A$. caliginosa) after exposure period 1, 2, 3 and 4 weeks.

\section{Effect of flufenoxuron and pyriproxyfen on growth changes of $A$. caliginosa}

The growth weight change of earthworms after exposed to $0,10,25$, 50,100 and $200 \mathrm{mg} / \mathrm{kg}$ artificial soil of flufenoxuron and $0,15,37.5,75$, 150 and $300 \mathrm{mg} / \mathrm{kg}$ of pyriproxyfen during the exposure period $(1,2$,
3 and 4 weeks) are shown in Figures 1 and 2. In the current conditions of the experiment, the weight of worms individual is slightly stable, in control after exposure period of 4 weeks. While earthworms exposed to artificial soil containing different concentrations of the tested IGRs, showed decreases in the ave rage weight. The general trend of the results showed that the weight loss in treating worms after an exposure period of 28 days, related to the increase in concentration of pesticides used. The observed decrease was prominent in growth after 7 days exposure period of flufenoxuron and after 14 days exposure period of pyriproxyfen. High growth inhibition of the earthworms was found with the high concentrations of flufenoxuron and pyriproxyfen.

\section{Inhibitory effects of flufenoxuron and pyriproxyfen on $\mathrm{AChE}$ activity}

Earthworm AChE activity was inhibited significantly $(\mathrm{P} 0.05<$, ANOVA) as shown in Table 3. The results were expressed as specific activity $\Delta \mathrm{OD}_{412} \cdot \mathrm{min}^{-1} \cdot \mathrm{mg}$ proteine ${ }^{-1}$ and the $\mathrm{I}_{50}$ values. In all tested

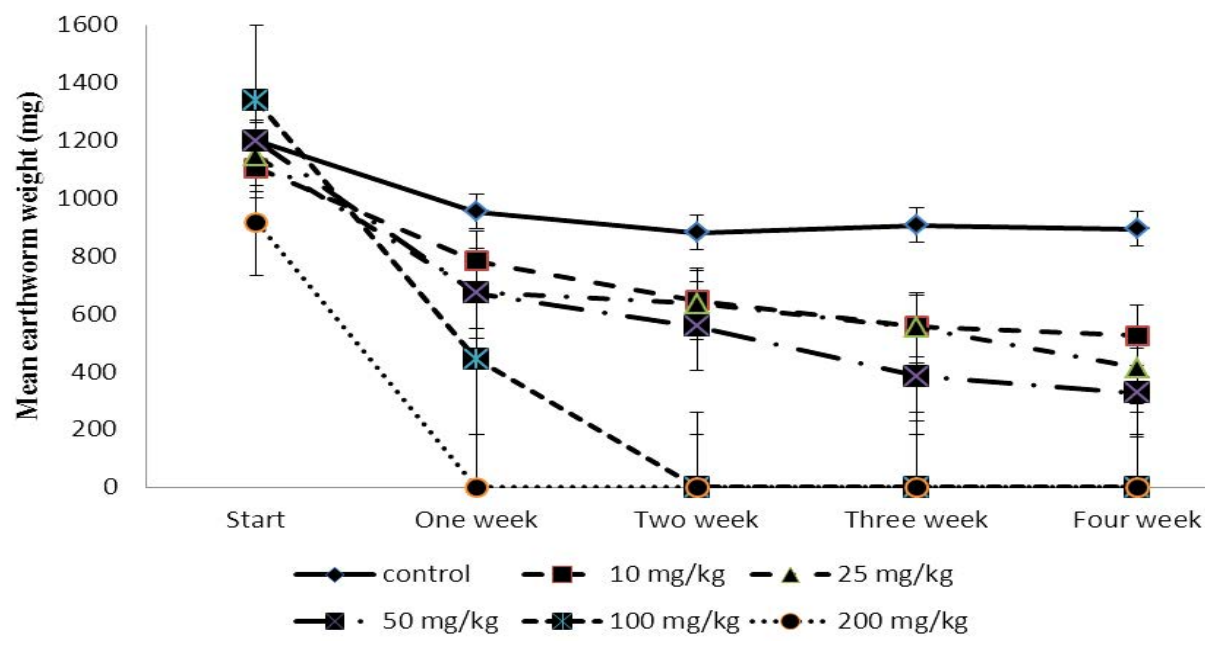

Figure 1: Mean weight \pm SE in earthworm $A$. caliginosa in artificial soil treated with flufenoxuron at different application rates in the laboratory. Growth weight measured when experiment started, 1, 2, 3 and 4 weeks after treatment.

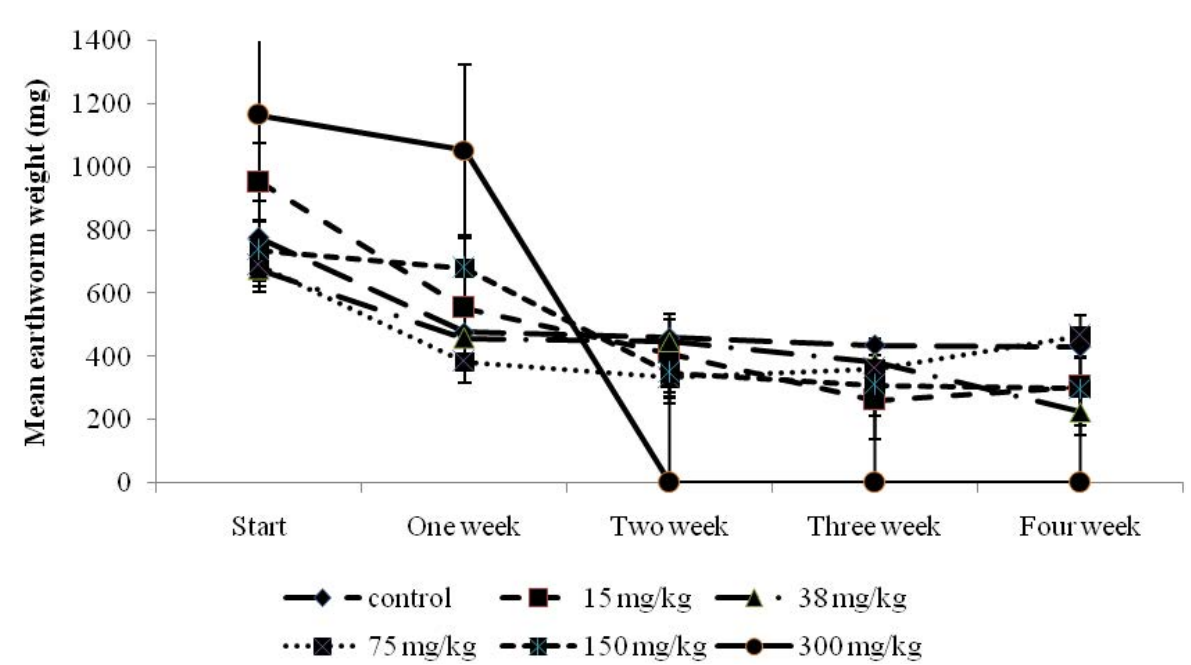

Figure 2: Mean weight \pm SE in earthworm A. caliginosa in artificial soil treated with pyriproxyfen at different application rates in the laboratory. Growth weight measured when experiment started, 1, 2, 3 and 4 weeks after treatment. 
concentrations the inhibitory effect increased in a dose -dependent manner. The highest inhibitory effect was determined after 4 weeks of treatment with flufenoxuron and pyriproxyfen. The percentage of inhibition was $46.12 \%$ in $100 \mathrm{mg} / \mathrm{kg}$ and $19.16 \%$ in $150 \mathrm{mg} / \mathrm{kg}$, for flufenoxuron and pyriproxyfen respectively. The inhibitory effect of the tested pesticides to AChE was further increased by day 14 of exposure. The lowest AChE activity was measured for the highest treated concentration under experimental study. On the other hand, the inhibitory effect of AChE activity increased in case of flufenoxuron more than pyriproxyfen $\left(\mathrm{I}_{50}=91.98\right.$ and $726.96 \mathrm{mg}$ a. $\mathrm{i} / \mathrm{kg}$ soil for flufenoxuron and pyriproxyfen, respectively).

\section{Inhibitory effects of flufenoxuron and pyriproxyfen on PPO activity of $A$. caliginosa}

PPO activity in earthworms exposed to different concentrations of flufenoxuron and Pyriproxyfen for 4 weeks in a potted soil analysis was examined in the laboratory and the results are presented in Table 4. All treated groups showed statistically significant differences from the control group $(\mathrm{P}<0.05)$, but not statistically significant differences in the enzyme inhibition were observed between the treated groups $(\mathrm{P}<0.05)$, as indicated in Table 4 . The enzyme activity in the flufenoxuron treated groups was inhibited by more than $33 \%$ at a high concentration. Compared with the control, the highest inhibition was recorded with earthworms exposed to flufenoxuron compared to pyriproxyfen. This has been achieved when recording a low value of the $I_{50}(8.20$ and 99.82 $\mathrm{mg}$ a.i $/ \mathrm{kg}$ soil for flufenoxuron and pyriproxyfen, respectively).

\section{Inhibitory effects of flufenoxuron and pyriproxyfen on GST} activity

The activity of glutathione-S-transferase (GST) in earthworms exposed to different concentrations of flufenoxuron and Pyriproxyfen for 4 weeks in a potted soil test in the laboratory was examined and the results are presented in Table 5 as specific activity $\left(\mathrm{OD}_{340} \cdot \mathrm{min}^{-1} \cdot \mathrm{mg}\right.$ protein $^{-1}$ ) and $\mathrm{I}_{50}$ values. Generally, a clear dose-response relationship was obtained with statistically significant differences $(\mathrm{P}<0.05$, ANOVA) between all data points and control after four weeks of exposure. The result revealed that the highest inhibitory effect was found in the highest concentration of the pesticide (decrease from 0.14 to 0.05 and from 0.14 to $0.01 \mathrm{OD}_{340} \cdot \mathrm{min}^{-1} \cdot \mathrm{mg}$ protein ${ }^{-1}$ for flufenoxuron and pyriproxyfen, respectively). Highest inhibition was achieved in earthworms exposed

\begin{tabular}{|c|c|c|c|c|}
\hline \multirow[b]{2}{*}{ Compounds } & \multirow[b]{2}{*}{$\begin{array}{l}\text { Concentration } \\
\text { (mg(a.i)/Kg } \\
\text { soil) }\end{array}$} & \multicolumn{3}{|c|}{ AChE Enzyme } \\
\hline & & $\begin{array}{c}\text { Specific activity } \\
\pm \mathrm{SE} \\
\left(\begin{array}{c}\Delta \mathrm{OD}_{412} \cdot \mathrm{min}^{-1} \cdot \mathrm{mg} \\
\left.\text { protein }^{-1}\right)\end{array}\right.\end{array}$ & $\begin{array}{c}\text { \% Inhibition } \\
\text { (\%l) }\end{array}$ & $\begin{array}{c}\mathrm{I}_{50} \\
\text { (mg a.i/kg } \\
\text { soil) }\end{array}$ \\
\hline \multirow{5}{*}{ Flufenoxuron } & 0 (untreated) & $0.0193^{a} \pm 0.000$ & $0.00^{h} \pm 0.00$ & \multirow{5}{*}{$\begin{array}{c}91.98 \\
(73.99-125.4)\end{array}$} \\
\hline & 10 & $0.0182^{b} \pm 0.001$ & $5.66^{9} \pm 0.04$ & \\
\hline & 25 & $0.0172^{c} \pm 0.001$ & $10.87^{f} \pm 0.02$ & \\
\hline & 50 & $0.0112^{f} \pm 0.001$ & $41.73^{b} \pm 0.12$ & \\
\hline & 100 & $0.0104^{9} \pm 0.001$ & $46.12^{\mathrm{a}} \pm 0.02$ & \\
\hline \multirow{4}{*}{ Pyriproxyfen } & 15 & $0.0182^{b} \pm 0.001$ & $5.67^{9} \pm 0.01$ & \multirow{4}{*}{$\begin{array}{c}726.96 \\
(315.15-6570)\end{array}$} \\
\hline & 37.5 & $0.0162^{d} \pm 0.003$ & $16.04^{e} \pm 0.02$ & \\
\hline & 75 & $0.0161^{d} \pm 0.001$ & $16.57^{\mathrm{d}} \pm 0.01$ & \\
\hline & 150 & $0.0156^{e} \pm 0.003$ & $19.16^{c} \pm 0.02$ & \\
\hline
\end{tabular}

Results are expressed as mean \pm standard error $(n=3)$. Values followed by the same letter within a column are not significantly different $(P \leq 0.05)$ according to Duncan's test. $1 \%=(\mathrm{A} 0-\mathrm{Ai} / \mathrm{A} 0) \times 100$ Where: $\mathrm{A} 0$ is the activity in the absence of inhibitor and $\mathrm{Ai}$ is the activity in the presence of inhibitor.

Table 3: Mean Specific activity of $\mathrm{AChE} \pm \mathrm{SE}$ and percentage inhibition $\pm \mathrm{SE}$ measured in mature earthworms ( $A$. caliginosa) after exposure to different concentrations of flufenoxuron and pyriproxyfen for four weeks.

\begin{tabular}{|c|c|c|c|c|}
\hline \multirow[b]{2}{*}{ Compounds } & \multirow[b]{2}{*}{$\begin{array}{c}\text { Concentration } \\
\text { (mg(a.i)/Kg } \\
\text { soil) }\end{array}$} & \multicolumn{3}{|c|}{ PPO Enzyme } \\
\hline & & $\begin{array}{c}\text { Specific activity } \\
\pm \mathrm{SE} \\
\left(\mathrm{OD}_{420} \cdot \mathrm{min}^{-1} \cdot \mathrm{mg}\right. \\
\left.\text { protein }^{-1}\right)\end{array}$ & $\begin{array}{c}\% \text { Inhibition } \\
\text { I (\%) }\end{array}$ & $\begin{array}{l}\mathrm{l}_{50} \\
\text { soil) }\end{array}$ \\
\hline \multirow{5}{*}{ Flufenoxuron } & 0 (Untreated) & $5.15^{\mathrm{a}} \pm 0.14$ & $0.00^{i} \pm 0.00$ & \multirow{5}{*}{$\begin{array}{c}8.2 \\
(0.0-21.11)\end{array}$} \\
\hline & 10 & $2.45^{d} \pm 0.67$ & $52.40^{\mathrm{e}} \pm 0.01$ & \\
\hline & 25 & $2.25^{\mathrm{e}} \pm 0.56$ & $56.31^{d} \pm 0.02$ & \\
\hline & 50 & $2.15^{f} \pm 0.02$ & $58.23^{c} \pm 0.01$ & \\
\hline & 100 & $1.71^{g} \pm 0.07$ & $66.76^{b} \pm 0.03$ & \\
\hline \multirow{4}{*}{ Pyriproxyfen } & 15 & $5.14^{\mathrm{a}} \pm 0.67$ & $0.18^{\mathrm{h}} \pm 0.01$ & \multirow{4}{*}{$\begin{array}{c}99.82 \\
(54.91-799.9)\end{array}$} \\
\hline & 37.5 & $4.06^{b} \pm 0.56$ & $21.16^{g} \pm 0.01$ & \\
\hline & 75 & $3.87^{c} \pm 0.02$ & $24.63^{f} \pm 0.12$ & \\
\hline & 150 & $1.42^{\mathrm{h}} \pm 0.07$ & $72.39^{a} \pm 0.02$ & \\
\hline
\end{tabular}

Results are expressed as mean \pm standard error $(n=3)$. Values followed by the same letter within a column are not significantly different $(P \leq 0.05)$ according to Duncan's test. $1 \%=(\mathrm{A} 0-\mathrm{Ai} / \mathrm{A} 0) \times 100$ Where: $\mathrm{A} 0$ is the activity in the absence of inhibitor and $\mathrm{Ai}$ is the activity in the presence of inhibitor.

Table 4: Mean Specific activity of PPO \pm SE and percentage inhibition \pm SE measured in mature earthworms ( $A$. caliginosa) after exposure period 4 weeks to different concentrations of flufenoxuron and pyriproxyfen.

\begin{tabular}{|c|c|c|c|c|}
\hline \multirow[b]{2}{*}{ Compounds } & \multirow[b]{2}{*}{$\begin{array}{c}\text { Concentration } \\
\text { (mg(a.i)/Kg } \\
\text { soil) }\end{array}$} & \multicolumn{3}{|c|}{ GST Enzyme } \\
\hline & & $\begin{array}{c}\text { Specific activity } \\
\pm \text { SE } \\
\left(\mathrm{OD}_{340} \cdot \mathrm{min}^{-1} \cdot \mathrm{mg}\right. \\
\left.\text { protein }{ }^{-1}\right)\end{array}$ & $\begin{array}{c}\% \text { Inhibition } \\
(\% \mathrm{l})\end{array}$ & $\begin{array}{l}\mathrm{lmg} \mathrm{a.i}_{50} \\
\text { soil) }\end{array}$ \\
\hline \multirow{5}{*}{ Flufenoxuron } & 0 & $0.14^{a} \pm 0.055$ & $0.00^{g} \pm 0.00$ & \multirow{5}{*}{$\begin{array}{c}50.30 \\
(43.16-59.75)\end{array}$} \\
\hline & 10 & $0.14^{a} \pm 0.056$ & $0.00^{g} \pm 0.00$ & \\
\hline & 25 & $0.09^{b} \pm 0.006$ & $35.72^{f} \pm 0.01$ & \\
\hline & 50 & $0.06^{c} \pm 0.003$ & $57.14^{d} \pm 0.015$ & \\
\hline & 100 & $0.05^{\mathrm{cd}} \pm 0.002$ & $64.29^{c} \pm 0.01$ & \\
\hline \multirow{4}{*}{ Pyriproxyfen } & 15 & $0.07^{b} \pm 0.004$ & $50.02^{\mathrm{e}} \pm 0.02$ & \multirow{4}{*}{$\begin{array}{c}13.56 \\
(0.0-31.32)\end{array}$} \\
\hline & 37.5 & $0.03^{\text {de }} \pm 0.003$ & $78.56^{b} \pm 0.01$ & \\
\hline & 75 & $0.03^{e} \pm 0.003$ & $78.57^{b} \pm 0.01$ & \\
\hline & 150 & $0.01^{f} \pm 0.002$ & $92.84^{a} \pm 0.01$ & \\
\hline
\end{tabular}

Results are expressed as mean \pm standard error $(n=3)$. Values followed by the same letter within a column are not significantly different $(P \leq 0.05)$ according to Duncan's test. $1 \%=(\mathrm{A} 0-\mathrm{Ai} / \mathrm{A} 0) \times 100$ Where: $\mathrm{A} 0$ is the activity in the absence of inhibitor and $\mathrm{Ai}$ is the activity in the presence of inhibitor.

Table 5: In vivo effect of different application rates of flufenoxuron and pyriproxyfen on GST activity in earthworm after exposure period 4 weeks.

to pyriproxyfen compared with flufenoxuron according to $I_{50}$ values $\left(\mathrm{I}_{50}=13.56\right.$ and 50.30 for pyriproxyfen and flufenoxuron, respectively).

\section{Discussion}

Earthworms are standard test organisms in soil toxicity testing. They have been broadly used to assess environmental impact of heavy metal pollution; however, the knowledge on toxic effects of pesticides upon these organisms is still very limited [26]. It is always difficult to establish causal relationships between the population density of earthworms and the degree of pollution in the field due to these varying factors which could be responsible for the observed condition [27]. However, higher densities of earthworms were found in areas at a distance from the cultivated area, in the same but undisturbed soil type. Earthworms are affected by pesticides either through skin contact or by feeding on contaminated litter in the soil. Primarily, these toxicants passing through the skin reach the coelomic fluid and are thus transported throughout the body. Previous studies suggested that earthworm skin has direct contact to the contaminated soils and is considered as a significant route to uptake of toxicants $[28,29]$. The IGRs inhibit chitin synthesis and kill the target insect by disturbing exoskeleton formation 
after molting [30], with minimal impact on non-target organisms [31]. Our studies demonstrate that the selected IGR insecticides have relatively low intrinsic toxicity to earthworms A. caliginosa according to the regulation of environmental risk assessment of agricultural pesticides [25] and a clear positive dose-response relationship between mortality of worm s and pesticide concentration was observed. The present observations on the ecophysiological toxicology may be useful for the protection and conservation of biological resources of worms. Despite of the low toxicity of the tested IGRs (Tables 1 and 2) comparing the toxicity of other pesticides from literatures, pyriproxyfen had a higher inhibitory effect after 4 weeks of exposure. These results were in agreeing with those of Mosleh et al. who determined that the $\mathrm{LC}_{50}$ of the IGR chlorfluazuron equal to $140 \mathrm{mg} / \mathrm{kg}$ soil compared to 0.68 , 73 and 127 for aldicarb, cypermethrin and profenofos, respectively. However, it was higher than atrazine and metalaxyl $\left(\mathrm{LC}_{50}=381\right.$ and $518 \mathrm{mg} / \mathrm{kg}$ soil, respectively). Earthworms' mortality can be used as a reliable indicator of environmental pollution. Kokta [32] reported that pesticides with $\mathrm{LC}_{50}$ value higher than $1000 \mathrm{mg} / \mathrm{kg}$ were harmless to earthworms in the field. Data from this study suggested that the two IGRs, flufenoxuron and pyriproxyfen have a lethal effect at high doses on the earthworms after acute exposure that can lead to a decrease in their population and to changes in the soil ecosystem. These data also indicated that these pesticides at their lower doses had little effect on earthworm mortality.

Growth inhibition can be a good indicator of chemical stress, chemical effects that can link to the dynamic energy and ultimately inhibit the growth of the tested organisms. The slight decrease in weight of earthworm control suggested that soil nutrients were sufficient to maintain the survival of earthworms, but insufficient to allow further growth. The results in growth inhibition treated by the two pesticides agreed with those reported in other pesticides. For example, a dose dependent decrease in the growth of E. fetida exposed to dieldrin at several sublethal concentrations was observed [33]. Significant growth inhibition on the earthworm Lumbricus rubellus were also observed when exposed to PAH pyrene [34]. Both lindane and deltamethrin inhibited the growth of earthworms, and this is possibly correlated with the strategy of an earthworm for natural survival: the reduction of food intake to avoid toxins. This strategy is commonly used in earthworms to avoid poisoning not only with heavy metals [35], but also organic chemicals such as pesticides [36,37]. Adjustments similar body were observed with isopod Porcellio dilatatus, with reduced consumption rates when exposed to high doses of endosulfan and its other parameters supply (assimilation rates, food assimilation efficiency) were affected so significantly, and ultimately, its growth was inhibited [38]. Mosleh et al. [10] reported that chlorfluazuron to $107 \mathrm{mg} / \mathrm{kg}$ soil $\left(\mathrm{LC}_{25}\right)$ reduced the growth rate of mature earthworms mature $A$. caliginosa and showed a negative logarithm (e), - 0.39 after 4 weeks of exposure compared to the control that had a positive $\log (\mathrm{e}),+0.34$. It should also be noted that although flufenoxuron and pyriproxyfen were the least toxic pesticides to earthworms, caused the greatest reduction in the growth rate of worm (Figures 1 and 2). This could be attributed to the high persistence of pesticides in soil or slow degradation in worms and subsequent elimination of the metabolites least. It may also indicate feeding inhibition with the earthworm regulate the intake of pesticides to reduce consumption and therefore probably affecting growth. This last strategy was shown to be commonly used to avoid poisoning by heavy metals and pesticides. Badawy et al. [39] reported that a comparative analysis of weight growth change in the earthworms A. caliginosa exposed to buprofezin, triflumuron and lufenuron in relation to different exposure times showed that the decrease in weight in all pesticide-treated worms was dose-dependent over the 28-day exposure period with increasing concentration. This result was in agreeing with our finding with two similar IGRs flufenoxuron and pyriproxyfen which represent the same behavior with $A$. caliginosa mature stage. Suthar [40] investigated the toxicological impact of methyl parathion on growth and reproduction performance in tropical earthworms: Metaphire posthuma, Lampito mauritii and Allolobophora parva. He found that the individual live weight loss was $27.0-37.0 \%$ in L. mauritii, $36.0-57.1 \%$ in M. posthuma and $1.2-11.0 \%$ in A. parva in different test concentrations. Martin [41] investigated the effect of certain toxic herbicides amitrole plus ammonium, thiocyanate 2,2DPA, trifluralin, glyphosate, propazine, and simazine) at 1, 10, and 100 $\mathrm{mg} / \mathrm{kg}$ of artificial soil against earthworms, while mortality was only observed in $100 \mathrm{mg} / \mathrm{kg}$ soil of trifluralin. Surviving worms in the other treatments lost weight at $100 \mathrm{mg} / \mathrm{kg}$ of artificial soil after 7 days.

The inhibition of AChE, PPO and GST in earthworms has been established for a number of species, including A. caliginosa $[38,42]$. With some variation, most of the concentrations used in our study resulted in a time-related response of specific activity of the enzyme in the earthworms (Tables 3, 4 and 5). The differences between the control of the experiment and the treatments were statistically significant $(\mathrm{P}<0.05)$ for the two pesticides. IGRs were used to control some insects on different crops, therefore, these pesticides present in the soil after application can reach and affect the non-target organisms such as earthworms. As the results of the present study, with a duration of four weeks, indicated a time-related effects of the pesticides, it seems reasonable to expect a chronic effect on these non-target organisms in the field soil. It is also known that a low enzyme activity could be associated with abnormal behavior, which could influence feeding and growth rate as shown in Figures 1 and 2.

The effects on AChE, PPO and GST activities of the worms were not also invest during the observation period and could be, as known to higher organisms, that recovery of enzyme activity requires days or even weeks $[43,44]$. The persistence of cholinesterase inhibition in earthworms has been investigated before. Booth et al. [45] explained that this enzyme inhibited continuously over time and that is not easily recovered. This suggests that the toxicity is associated with the accumulation of these IGRs in excess amounts and with inhibition of AChE, which is injurious to the earthworms. Also, this result was in agreeing with Connell et al. [46] who determined the effect of pesticide Bio-accumulation in the contaminated soil to an earthworm. It can assume that toxicity testing may be useful for screening of pesticides in particular sublethal effects on AChE, PPO and GST activities of earthworms. Information on acute and chronic effects may be significant for understanding the ecotoxicological effects on earthworms.

\section{Conclusion}

Flufenoxuron and pyriproxyfen as toxic IGRs were low toxic to earthworms under acute exposure. The present study showed that the highest inhibitory effect was found in high concentrations of the pesticide after four weeks of exposure. Results also showed that the pyriproxyfen was more impact on the earthworm from flufenoxuron after exposure for a period of four weeks. While flufenoxuron was highest inhibition of the growth and the activity of AChE, PPO in the earthworm from pyriproxyfen. On the other hand the pyriproxyfen was highest inhibition of GST activity compared to the untreated group. These results suggest that changes in weight growth and enzyme activity during periods of exposure may be sensitive parameters to assess the extent of damage caused by pesticides because they 
Citation: Nasr HM, Badawy ME (2015) Biomarker Response and Biomass Toxicity of Earthworms Aporrectodea caliginosa Exposed to IGRs Pesticides. J Environ Anal Toxicol 5: 332. doi:10.4172/2161-0525.1000332

Page 6 of 7

provide early warning responses relative to those occurring naturally in the environment. The chronic presence in the soil of IGRs such as Flufenoxuron and pyriproxyfen in combination with other agricultural chemicals could have contributed to causing the low abundance of earthworms in these soils. Furthermore, the results contribute to overcome the lack of ecotoxicological data on IGR in tropical conditions, but more evidence is needed with different soil invertebrates to improve pesticide risk analysis.

\section{References}

1. Venkateswara Rao J (2006) Biochemical alterations in euryhaline fish (Oreochromis mossambicus) exposed to sub-lethal concentrations of an organophosphorus insecticide, monochrotophos. Chemosphere 65: 18141820.

2. Kathuria $V(2007)$ Informal regulation of pollution in a developing country: Evidence from India. Ecol Econ 63: 403-417.

3. Sparling DW, Fellers G (2007) Comparative toxicity of chlorpyrifos, diazinon, malathion and their oxon derivatives to larval Rana boylii. Environ Pollut 147: 535-539.

4. Loewy RM, Carvajala LG, Novellia MA, Pechen De D'Angelo M (2006) Azinphos methyl residues in shallow groundwater from the fruit production region of northern Patagonia. Argentina J Environ Sci Health Part B 41: 869-881.

5. Bartlett MD, Briones MJI, Neilson R, Schmidt O, Spurgeon D, Creamer RE (2010) A critical review of current methods in earthworm ecology: from individuals to populations. Eur J Soil Biol 46: 67-73.

6. Lee KE (1985) Earthworms. Their Ecology and Relations to Soils and Land Use, First. Academic Press, Sydney.

7. Zhou SP, Duan CQ, Fu H, Chen YH, Wang XH, et al. (2007) Toxicity assessment for chlorpyrifos-contaminated soil with three different earthworm test methods. J Environ Sci (China) 19: 854-858

8. Ouellet G, Lapen DR, Topp E, Sawada M, Edwards M (2008) A heuristic model to predict earthworm biomass in agro ecosystems based on selected management and soil properties. Appl Soil Ecol 39: 35-45.

9. Jouquet P, Plumere T, Thu TD, Rumpel C, Duc TT, et al. (2010) The rehabilitation of tropical soils using compost and vermin Compost is affected by the presence of endogeic earthworms. Appl Soil Ecol 46: 125-133.

10. Mosleh YY, Ismail SM, Ahmed MT, Ahmed YM (2003) Comparative toxicity and biochemical responses of certain pesticides to the mature earthworm Aporrectodea caliginosa under laboratory conditions. Environ Toxicol 18: 338346.

11. Nahmani J, Hodson ME, Black S (2007) Effects of metals on life cycle parameters of the earthworm Eisenia fetida exposed to field-contaminated, metal-polluted soils. Environ Poll 149: 44-58.

12. Suthar S, Singh S, Dhawan S (2008) Earthworms as bioindicator of metals ( $\mathrm{Zn}, \mathrm{Fe}, \mathrm{Mn}, \mathrm{Cu}, \mathrm{Pb}$ and $\mathrm{Cd}$ ) in soils: Is metal bioaccumulation affected by their ecological category? Ecol Eng 32: 99-107.

13. Lourenço JI, Pereira RO, Silva AC, Morgado JM, Carvalho FP, et al. (2011) Genotoxic endpoints in the earthworms sub-lethal assay to evaluate natural soils contaminated by metals and radionuclides. J Hazard Mater 186: 788-795.

14. Nasr HM, Badawy MEI, Rabea EI (2010) Toxicity and biochemical study of two insect growth regulators, buprofezin and pyriproxyfen, on cotton leafworm Spodoptera littoralis. Pesticide Biochem Physiol 98: 198-205.

15. Koehler PG, Patterson RS (1991) Incorporation of pyriproxyfen in a German cockroach (Dictyoptera: Blattellidae) management program. J Econ Entomol 84: $917-921$.

16. Aribi N, Smagghe G, Lakbar S, Soltani-Mazouni, Soltani N (2006) Effects of pyriproxyfen, a juvenile hormone analog, on development of the mealworm, Tenebrio molitor. Pesticide Biochem Physiol 84: 55-62.

17. Cutler GC, Scott-Dupree CD, Tolman JH, Harris CR (2007) Field efficacy of novaluron for control of Colorado potato beetle (Coleoptera: Chrysomelidae) on potato. Crop Prot 26: 760-767.

18. Heimbach F (1984) Correlation between three methods for determining the toxicity of chemicals to earthworms. Pesticide Science 15: 605-611.

19. OECD (1984) OECD guidelines for testing chemicals. Test 207: earthworm, acute toxicity test. Organization for Economic Co-operation and Development (OECD), Paris.

20. Finney DJ (1971) Probit Analysis, 3rd edn. Cambridge University Press, Cambridge, UK.

21. Lowry OH, Rosebrough NJ, Farr AL, Randall RJ (1951) Protein measurement with the Folin phenol reagent. J Biol Chem 193: 265-275.

22. Ellman GL, Courtney KD, Andres V Jr, Feather-Stone RM (1961) A new and rapid colorimetric determination of acetylcholinesterase activity. Biochem Pharmacol 7: 88-95.

23. Fattouch S, Raboudi-Fattouch F, Gil Ponce J, Forment J, Lukovic D, et al (2010) Concentration dependent effects of commonly used pesticides on activation versus inhibition of the quince (Cydonia Oblonga) polyphenol oxidase. Food Chem Toxicol 48: 957-963

24. Saint-Denis M, Labrot F, Narbonne JF, Ribera D (1998) Glutathione glutathione-related enzymes, and catalase activities in the earthworm Eisenia fetida andrei. Arch Environ Contam Toxicol 35: 602-614.

25. MEPPRC (Ministry of Environment Protection of the People's Republic of China) (1990) Safety evaluation of chemical pesticide. Pesticide Science and Administration 2: 1-9.

26. Castellanos LR, Hernandez TCS (2007) Earthworm biomarkers of pesticide contamination: current status and perspectives. J Pestic Sci 32: 360-371.

27. Curry JP (2004) Factors affecting the abundance of earthworms in soils. In Edwards CA (Ed) Earthworm Ecolgy. CRC Press, Boca Raton. pp: 91-114.

28. Jager T, Fleuren RH, Hogendoorn EA, de Korte G (2003) Elucidating the routes of exposure for organic chemicals in the earthworm, Eisenia andre (Oligochaeta). Environ Sci Technol 37: 3399-3404

29. Vijver MG, Vink JPM, Miermans CJH, Gestel CAMV (2003) Oral sealing using glue: a new method to distinguish between intestinal and dermal uptake of metals in earthworms. Soil Biol Biochem 35: 125-132.

30. Schneider M, Smagghe G, Pineda S, Viñuela E (2008) The ecological impact of four IGR insecticides in adults of Hyposoter didymator (Hym., Ichneumonidae): pharmacokinetics approach. Ecotoxicology 17: 181-188.

31. Carmo EL, Bueno AF, Bueno RCOF (2010) Pesticides electivity for the insect egg parasitoid Telenomus remus. Bio Control 55: 455-464.

32. Kokta C (1992) A laboratory test on sublethal effects of pesticides on Eisenia fetida," in Ecotoxicology of Earthworms, H Becker, PJ Edwards, PW GreigSmith, F Heimbach (Eds) Intersept Press. pp: 55-62.

33. Shi Y, Shi Y, Wang X, Lu Y, Yan S (2007) Comparative effects of lindane and deltamethrin on mortality, growth, and cellulase activity in earthworms (Eisenia fetida). Pesticide Biochem Physiol 89: 31-38

34. Brown PJ, Long SM, Spurgeon DJ, Svendsen C, Hankard PK (2004) Toxicological and biochemical responses of the earthworm Lumbricus rubellus to pyrene, a non-carcinogenic polycyclic aromatic hydrocarbon. Chemosphere 57: $1675-1681$.

35. Burrows LA, Edwards CA (2002) The use of integrated soil microcosms to predict effects of pesticides on soil ecosystems. Eur J Soil Biol 38: 245-249.

36. Nunes NMET, Espndola ELG (2012) Sensitivity of Eisenia andrei (Annelida Oligochaeta) to a commercial formulation of abamectin in avoidance tests with artificial substrate and natural soil under tropical conditions. Ecotoxicol 21: 1063-1071.

37. Wang JH, Zhu LS, Liu W, Wang J, Xie H (2012) Biochemical responses of earthworm (Eisenia foetida) to the pesticides chlorpyrifos and fenvalerate. Toxicol Mech Methods 22: 236-241.

38. Ribeiro S, Sousa J, Nogueira AJA, Soares AMVM ( 2001) Effect of endosulfan and parathion on energy reserves and physiological parameters of the terrestrial isopod Porcellio dilatatus. Ecotoxicol Environ Safety 49: 131-138.

39. Badawy MEI, Kenawy A, El-Aswad AF (2013) Toxicity Assessment of Buprofezin, Lufenuron, and Triflumuron to the Earthworm Aporrectodea caliginosa. Int $\mathrm{J}$ Zool 9.

40. Suthar S (2014) Toxicity of methyl parathion on growth and reproduction of three ecologically different tropical earthworms. Int J Environ Sci Technol 11 191-198.

41. Martin NA (1982) The effects of herbicides used on asparagus on the growth 
Citation: Nasr HM, Badawy ME (2015) Biomarker Response and Biomass Toxicity of Earthworms Aporrectodea caliginosa Exposed to IGRs Pesticides. J Environ Anal Toxicol 5: 332. doi:10.4172/2161-0525.1000332

rate of the earthworm Allolobophora caliginosa, In Proceedings of the 35th New Zealand Weed and Pest Conference: 238-330.

42. Ribera D, Narbonne JF, Arnaud C, Saint-Denis M (2001) Biochemical responses of the earthworm Eisenia fetida andrei exposed to contaminated artificial soil, effects of carbaryl. Soil Biol Biochem 33: 1123-1130.

43. Chambers JE, Carr RJ, Boone JS, Chambers HW (2001) The metabolism of organophosphorous insecticides. In Handbook of Pesticide Toxicology, Agents, Krieger R (Ed) Academic Press, San Diego, California, USA 2: 919-929.
44. Booth LH, Heppelthwaite V, McGlinchy A (2000) The effect of environmental parameters on growth, cholinesterase activity and glutathione S-transferase activity in the earthworm (Aporrectodea caliginosa). Biomarkers 5: 46-55.

45. Booth LH, Hodge S, O'Halloran K (2001) Use of biomarkers in earthworms to detect use and abuse of field applications of a model organophosphate pesticide. Bull Environ Contam Toxicol 67: 633-640.

46. Connell DW, Markwell RD (1990) Bio-accumulation in the soil to earthworm Chemosphere 20: 91-100. 